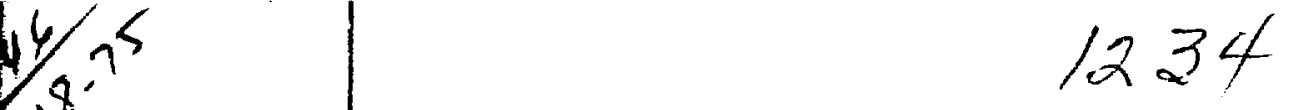

LA-5868-MS

Informal Report

UC-79b

Reporting Date: January 1975

lssued: February 1975

\title{
PINTEMP: A Computer Program for Fuel Element Design Calculations
}

by

Jerry F. Kerrisk 
in the interest of prompt distribution, this LAMS report was not edited by the Technical Information stalf.

This work was supported by the US Energy Research and Develop. ment Administration, Division of Reactor Research and Development.

Printed in the Uniled Stale of Amoriex. Arrilabls from National Technical Information Sorvice

U.S. Department of Commerce

5285 Port Royal Road

Springtiald, VA 22151

Price: Prinied Copy 40.00 Microtiche \$2.25

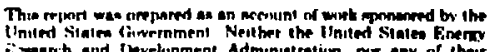

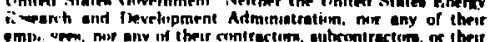

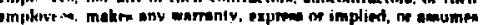

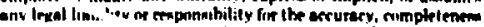

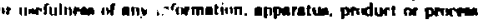

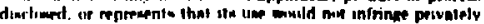
imerietl natis 
NOTICE

This report was prepated as an aciount of work sponsored by the United States Goverument. Nither the United States nor the United States Energy Research and Development Administration, nor any of their employees not any of their contractors, subcontractors, or their employees, makes any warranty, express or implied, or assumes any lepa liability or responsibility for the aceuracy, completeness or usefulness of any information, apparatus, ptodes process disclosed, or represents that its use would not infringe privately owned rights.

PINTEMP

A COMPUTER PROGRAM FOR FUEL ELEMENT

DESIGN CALCULATIONS

by

Jerry F, Kerrisk

ABSTRACT

The computer program PINTEMP has been written to perform design calculations for fuel elements in the EBR-II reactor. The program calculates fuel element and sodium coolant temperatures, thermal stresses in the clad, and fission gas generated in the fuel during steady state irradiation.

\section{INTRODUCTION}

The computer program PINTEMP calculates temperatures in fuel elements being irradiated in EBR-II. The program considers only single elements and assumes one-dimensional (radial), steady state heat flow. For the calculation, an element is partitioned into a series of concentric cylindrical regions. The outer region transfers heat to a coolant flowing axially along the element. The coolant temperature is defined by integration of the element power generation from the inlet to tise axial plane of interest.

Fuel element fission power generation can be defined from the input of linear power as a function of axial location, or it can be calculated from input fuel composition and peak fission rates. Power generation from fission heat is allowed in only one region. An auxiliary heat generation, generally considered gamma heating, can be applied to any number of regions.

If desired, the program will correct the input region radii for thermal expansion. This requires an iterative procedure at any axial location since the dimen- sions of a region affect the heat conduction through the region. Iteration continues until the maximum temperature change from one iteration to the next is less than $0.01 \%$.

Thermal property data for a number of materials of interest are stcred in the program. This allows the material which composes a particular region to be speciffed without the additional input of properties. The thermal conductivity is considered to be a function of temperature. The coolant is assumed to be sodium, so that sodium enthalpy, heat capacity and density are also stored as functions of temperature.

In addition to calculating temperatures, the program calculates a number of other items of interest. Thermal stresses are calculated in hollow cylindrical regions using the plane strain assumption and stainless steel properties. Tangential and radial stresses are determined. The program also calculates the fission gas generated in the fuel at a specified goal burnup, and the irradiation time required to achieve the goal burnup in EBR-II. Radial and axial temperature plots can be made. 


\section{PROGRAM OUTLINE}

The fuel element is divided into a number of concentric cylindrical regions. For any region $i$, the temperature is defined by the equation

$$
\nabla\left(K_{i}\left(T_{i}\right) \nabla T_{i}\right)=-q_{i}
$$

where $T_{i}$ is the temperature, $q_{i}$ is the volumetric energy generation, and $k_{i}\left(T_{i}\right)$ is the thermal conductivity in region $i$. The temperature dependence of the thermal conductivity is assumed to be

$$
K_{i}\left(T_{i}\right)=a_{i}+b_{i} T_{i}+c_{i} T_{i}^{2}
$$

where $a_{i}, b_{i}$, and $c_{i}$ are constants for region $i$. Using the Kirchoff transformation and standard solution methods, ${ }^{1}$ the solution to Eq. (1) can be written as

$T_{1}\left(1+\frac{1}{2} \frac{b_{1}}{a_{1}} T_{1}+\frac{1}{3} \frac{c_{1}}{a_{1}} T_{1}^{2}\right)=A_{1}-\frac{a_{1}}{a_{1}} \frac{r^{2}}{4}$

for $i=1$, and

$$
\begin{aligned}
& T_{i}\left(1+\frac{1}{3} \frac{b_{i}}{a_{i}} T_{i}+\frac{1}{3} \frac{c_{i}}{a_{i}} T_{i}{ }^{2}\right) \\
& =A_{i}+B_{i} \ln \left(\frac{r}{r_{i}}\right)-\frac{q_{i}}{a_{i}} \frac{r^{2}}{4}
\end{aligned}
$$

for $i>1$. The quantity $r_{i}$ is the outside surface radius of region $i$, and $A_{1}$ and $B_{i}$ are constants which must be determined using boundary conditions. It should be noted that Eqs. (3) and (4) are impllcit functions of $T_{1}$, so that for any given values of the constants and radius, $T_{i}$ must be obtained by some iterative technique.

The boundary conditions applied at the repion surfaces match the temperature and heat flux for internal boundaries. Thus

$$
T_{i}\left(r_{i}\right)=T_{i+1}\left(r_{i}\right)
$$

and

$$
k_{i}\left(T_{i}\right)\left(\frac{\partial T_{i}}{\partial r}\right)_{r_{i}}=k_{i+1}\left(T_{i+1}^{\prime}\left(\frac{\partial T_{i+1}}{\partial r}\right)_{r_{i}}\right.
$$

at the interface between regions $i$ and $i+1$. The boundary condition between the outer region surface and the

flowing coolant is

$-k_{n}\left(T_{n}\right)\left(\frac{\partial T_{n}}{\partial r}\right)_{r_{n}}=h\left(T_{s}(z)\right)\left(T_{n}\left(r_{n}\right)-T_{s}(z)\right)$

where the subscript $n$ denotes the outer region, $h\left(T_{s}(z)\right)$ is the heat transfer coefficient to the coolant, and $\mathrm{T}_{\mathrm{s}}$ (z) is the bulk coolant temperature at the axial location $z$. Assuming the value of $T_{s}(2)$ is known, the boundary conditions allow the constants $A_{1}$ and $B_{1}$ in Eqs. (3) and (4) to be calculated for each region. The $B_{1}$ are first calculated from

$B_{i+1}=\frac{a_{i}}{a_{i+1}} \quad B_{i}-\frac{r_{i}^{2}}{2 a_{i+1}}\left(q_{i}-q_{i+1}\right)$,

and the requirement that $B_{t}=O$ (see Eq. (3)). The outside surface $\left(r=r_{n}\right.$ ) temperature is then calculated as

$T_{n}\left(r_{n}\right)=T_{s}(z)-\frac{1}{h\left(T_{s}(z)\right)}\left[\frac{a_{n} B_{n}}{r_{n}}-\frac{q_{n} r_{n}}{2}\right]$,

and $A_{n}$ is calculated from

$$
\begin{aligned}
A_{n}= & T_{n}\left(r_{n}\right)\left(1+\frac{1}{a_{n}} T_{n}\left(r_{n}\right)+\frac{1}{3} \frac{c_{n}}{a_{n}} T_{n}^{2}\left(r_{n}\right)\right) \\
& +\frac{q_{n} r_{n}^{2}}{4 a_{n}} .
\end{aligned}
$$

Subsequent $A_{i}$ are determined by calculating $/ s_{i-1}$ from the known $A_{i}$ and the surface temperature rif the interface between regions $1-1$ and $i$,

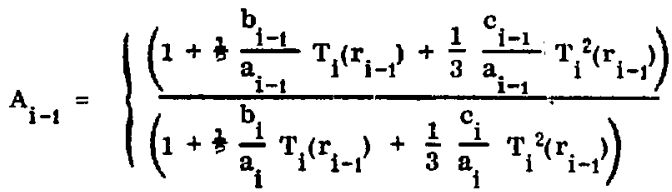

$$
\begin{aligned}
& \left.\left(A_{i}+B_{i} \ln \left(\frac{r_{1-1}}{r_{i}}\right)-\frac{q_{i} r_{1-1}}{2 a_{i}}\right)\right\} \\
& +\frac{q_{1-1} r_{i-1}^{2}}{4 a_{i-1}} \text {. }
\end{aligned}
$$


Thts complates at detinttion of the constank in Eq. ist

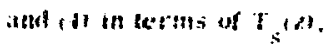

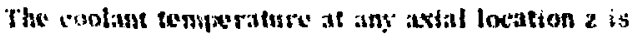

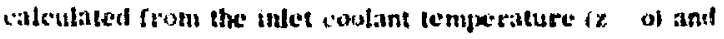
the total enures henseated irom the intet up to $z$. If (d,plis is the total power geskeration per unit lenath at the ixial Ioxation $x$, then

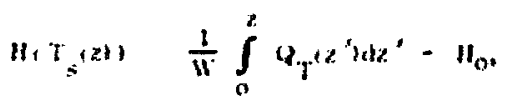

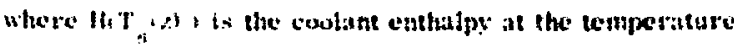

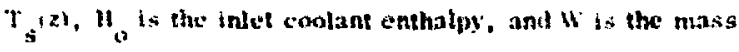

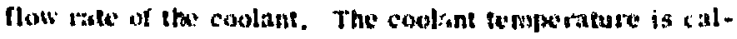
culated fron the known flifitional relationisip ixetween

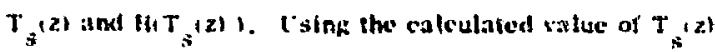
and the scheme previously thefined for teter tointing the constants $A_{i}$ and $B_{1}$, Fqs. $(B)$ and , 1 can be used to calculate the temperature at any adtial becation an any region at the axiol location 2 .

The volumetric enerext teneration in any rekioss can have two components, fission heating and gomnti heating. Fission heating is alluwed in onit anc regtors. Fission heating cthe can lo input as the limear powiog at a series of axial lowations. If this option is used, the walm unctric energy genexation is calculated from the lineis power and the region dintonsions. Fission heating eat also the calcutated from input dita on the fuel conposition

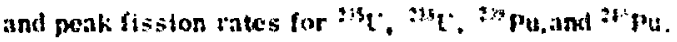

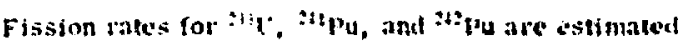
fom the input fission riste datn. The prostam has storcel data of relatios axtal fission rates and jegat lo axial atyarage fission rates for the ftsstonable isotopes. These dath were oblaind drom the EBR-It ciuidt." but can be easily niodified by changing a dith statenient. The volumetrite cnergy generation at any axial location ts calletlated fion the proxluct of the tsotope concentrution, the peak fisition rate for that isotope, and the relative axial fission rate for the isotope at the axial location. The energi generation for each flssionable isotope is summed to give the tohl volumetric enery generation from fission. The fission energ is assumed to be $196 \mathrm{MeV} / \mathrm{C}$ ission. This includes a contribution from gamma heating
In the fisiton region so thit an additanal gamma heating contribution is not issumed. Garmm heating in the other materials is imput as a porver per unit mass $\left(w^{\prime}\right.$ 'p for each material. The volumetric energs generation from famma healing is calculated from the pewer per unit mass, the region tensity and dimensions, and stored relative axial grimma heating data chtained from the EDR. I Cuside. In practice only stindess sted gamma beating is considerod for usual element designs.

The thermal conductivity of each material is defined as a polynomial in temperature \&qs. 23 . Table ! lists tive coefficients used for the mateints currenty: astaflable in the progran. The thermat conductivity of 11. Pu, $)$ C cuel was obrained from in evaluation of expe:-

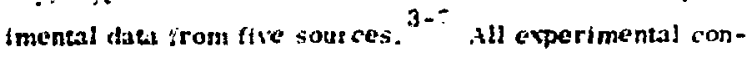
ductivitics were corrected to $l 00$ theoretieal density before the cualuselon, using the expression

$$
h_{p} k_{0}\left(\frac{1-p}{1-p}\right)
$$

where $k_{0}$ and $k_{p}$ are the conductivities at zero pore volume fristion and at pors volume fraction p, respectively. the thermal conductivity of $1 \mathrm{C}^{*}$. Pu. $1 \mathrm{~N}$ was obtatned from an evaluatlon of the experimental data from four sourccs. $5,6,5,9$ porosde corrections similar to those made for the carblete were made for the nitride. The thermal conductivitics of swinless stecl, ${ }^{10}$ sodium, 11 helium, 12 and fission fas were oblained from standard reference scurees. The fistion gas was assumed to be $15^{-}$kippon and $\$ 5$ venon. Stnee shermal conductivities of krppion and tenon were not avalable at high temperatures, the high cenperature bohavior was estiniated from the thermat conductivity of argon. Hetueen $200^{\circ} \mathrm{C}$ and $500^{\circ} \mathrm{C}$ the ratio of the thermal conductivity of hippton to that of argon ts $0,5 j$. 12 and the ratio of the thermal concisctivin. of xenon to that of argon is $0,35,12$ Thus, fission gais theramal conductivity $f_{f}$ wes estimated as

$k_{\text {fg }} 10.151,0.551 k_{A r}-10.551(0.35) k_{A t}-0.35 k_{A I}$ where $k_{A r}$ is the thermal conductivity of argon. ${ }^{12}$ in addition to simple conduction, a Hnear approximation to radiation transport across a gas gap is allowed. 13 
TABLE I

THE RMAL CONDUCTIVITY COEFFICIENTS

$k=a+b T+c T^{2}$ with $T$ in ${ }^{\circ} \mathrm{C}$ and $k$ in $W / \mathrm{cm}^{\circ} \mathrm{C}$

\begin{tabular}{|c|c|c|c|}
\hline Material $^{(a)}$ & 3 & b & c \\
\hline$\left(\mathrm{U}_{\mathrm{B}} \mathrm{Pu}, \mathrm{e}\right) \mathrm{C}$ & 0.1270 & $1.062 \times 10^{-4}$ & $-2.797 \times 10^{-8}$ \\
\hline$\left(U_{.8} \mathrm{Pu} .{ }_{2}\right) \mathrm{N}$ & 0.1252 & $7.228 \times 10^{-5}$ & $-2.033 \times 10^{-g}$ \\
\hline $\begin{array}{l}304 \text { or } 316 \\
\text { Stainless Steel }\end{array}$ & 0.1383 & $1.568 \times 10^{-9}$ & $-1.446 \times 10^{-9}$ \\
\hline Sodium & 0.9182 & $-5.373 \times 10^{-4}$ & $8.778 \times 10^{-B}$ \\
\hline Helium & $1.494 \times 10^{-3}$ & $3.063 \times 10^{-6}$ & $-1.888 \times 10^{-10}$ \\
\hline Fission Gas & $7.321 \times 10^{-5}$ & $1.258 \times 10^{-7}$ & $-1.106 \times 10^{-11}$ \\
\hline
\end{tabular}

(a) Solids are 100\% theoretical density. Fuel thermal conductivities corrected for porosity using the relation $k_{p}=k_{0}\left(\frac{1-p}{i+p}\right)$, where $k_{o}$ and $k_{p}$ are the conductivities at zero porosity and pore fraction $p$.

The heat transfer coefficient between the sodium coolant and the outside region surface $(h)$ is calculated from $^{14}$

$$
\mathrm{Nu}-5.0+0.0 .25(\mathrm{Pe})^{0.8}
$$

where the Nussalt number is defined as

$$
\mathrm{Nu}=\mathrm{h} \mathrm{D}_{\mathrm{e}} / \mathrm{k}
$$

and the Peciet number is defined as

$$
P e=D_{e} G C_{p} / k .
$$

In these definitions $D_{e}$ is the equivalent dtameter of the flow channel, $k$ is the thermal conductivity of the sodium isee Table $\mathrm{n}, \mathrm{C}_{\mathrm{j}}$ is the heat capncity of the sodium, and $G$ is the mass velocity of the sodium. The equivalent diameter of a flow channel is calculated as 4 times the flow area divided by the wetted solid perimeter. The sodium heat capacity is calculated from

$$
C_{p}=0.8815+2.793 \times 1 G^{-1} T_{k}+9.782 \times 10^{4} / T_{k}^{2}
$$

where $r_{p}$ is in joules $/ g{ }^{\circ} \mathrm{C}$ and $T_{k}$ is the temperature in K. $^{15}$ The enthalpy of sodium is calculated by integrating the heat capacity

$$
H(T)-H\left(T_{0}\right)=\int_{T_{0}}^{T} c_{p}\left(T^{\prime}\right) d^{\prime} T^{\prime} .
$$

The thermal stresses in hollow cylindrical regions are calculated from the known temperature distribution in the region, and the relations ${ }^{i 6}$

$$
\begin{aligned}
\sigma_{r_{i}}(r)= & \frac{\alpha E}{1-\nu} \frac{1}{r^{2}}\left[\frac{\left(r^{2}-r_{i-i}^{2}\right)}{\left(r_{i}^{2}-r_{i-1}^{2}\right)} \int_{r_{i-1}}^{r_{i}} T_{i}(r) r i r\right. \\
& \left.-\int_{r_{i-1}}^{r} T_{i}(r) r d r\right] .
\end{aligned}
$$

and 
$\sigma_{\theta_{i}}(r)=\frac{\alpha E}{1-v} \frac{1}{r^{2}}\left[\frac{\left(r^{2}+r_{i-1}^{2}\right)}{\left(r_{i}^{2}-r_{i-1}^{2}\right)} \int_{r_{i-1}}^{r_{i}} T_{i}(r) r d r+\int_{r_{i-1}}^{r} T_{i}(r) r d r-T_{i}(r) r^{2}\right]$,

where $\sigma_{r_{i}}(r)$ and $\sigma_{\theta_{i}}(r)$ are the radial and tangential thermal stresses in region $i$ at the radial location $r, \alpha$ is the thermal expansion coefficient, $E$ is Young's modulus, and $v$ is Poisson's ratin. The integrals required are evaluated numerically. The material constant $\frac{\alpha E}{1-\nu}$ for stainless steel is calculated from

$\frac{\alpha E}{1-\nu}=\left(\frac{6.8948}{1-0.3}\right)\left(470.1+0.1043 \mathrm{~T}-1.955 \times 10^{-4} \mathrm{~T}^{2}\right)$.

where the result has the units $\mathrm{kPa} /{ }^{\circ} \mathrm{C}$ and $\mathrm{T}$ is in ${ }^{\circ} \mathrm{C}$.

When the fission energy generation is calculated from the fuel composition, the fission gas generation in the fuel can also be calculated. This calculation uses an input value of the peak goal burnup in at. ' ${ }^{\prime}$, the peak/axial average fission rate ratios for the various fissionable isotopes obtained from the EBR-II Guide, ${ }^{2}$ and the fission product yield data of Meek and Rider. ${ }^{17}$ Yields of ${ }^{43} \mathrm{Kr}$, ${ }^{84} \mathrm{Kr},{ }^{85} \mathrm{Kr},{ }^{86} \mathrm{Kr},{ }^{131} \mathrm{Xe},{ }^{132} \mathrm{Xe},{ }^{134} \mathrm{Xe}$, and ${ }^{331} \mathrm{Xe}$ are calculated for the fuel element. The ${ }^{85} \mathrm{Kr}$ generation is no: corrected for decay. In addition, the program estimates th" irradiation time based on the input fission rates and the goal burnup.

Two other properties used during the calculations are material densities and thernal expansion coefficients. The material densities are used to interconvert material weights and volumes where required. The therma! expansion coefficients are used for correction of the region radii. Table II lists the values in use and the references for the thermal expansion data.

\section{PROGRAM LISTING}

Appendix A contains a listing of PINTE MIP. It includes the main program (PINTEMP), three function subroutines (THC, THCR, and TEMPR), and two subrout,nes
TABLE II

Mascellaneous Material. PROPE.rTIES

\begin{tabular}{|c|c|c|c|}
\hline & $\begin{array}{l}\text { Material Density } \\
\text { (1000\% TD) } \times 1 \mathrm{~cm}^{3}\end{array}$ & $\begin{array}{l}\text { Thermal Expansion } \\
\text { Coefticlent }{ }^{\circ} \mathrm{C}^{-3}\end{array}$ & $\begin{array}{c}\text { Thermal Expansich } \\
\text { Rrlerence }\end{array}$ \\
\hline (U., Pu, ${ }_{2} \mathrm{C}$ & 13.43 & $1.2 \times 10^{-5}$ & 18 \\
\hline (U.0.Pu & 14.16 & $0.9 \times 10^{-3}$ & $\theta$ \\
\hline $\begin{array}{l}304 \text { or } 316 \\
\text { Stajnlezs Steel }\end{array}$ & 8.0 & $1.83 \times 10^{-3}$ & 19 \\
\hline
\end{tabular}

(TEMCAL and FISGAS). In addition to the routines shown in Appendix $A$, there are a number of Los Alamos Scientific Laboratory standard program library subroutines which are called. These include a set of spline parameter evaluation and spline integration routines, and $35 \mathrm{~mm}$ illm plotting routines.

A description of the input data required for the program is contained in the program listing.

\section{REFERENCES}

1. H. S. Carslaw and J. C. Jaeger, Conduction of Heat in Sollds (Oxford University Press, London, 1959), pp. 10-11 and pp. 188-191.

2. Guide for Irradiation Experiments in E.BR-II, Revision 5, October, 1972, EBR-Ii Project, Argonne National Laboratory, Argonne, nlinois, Appendix C.

3. K. W. R. Johnson and J. A. Leary, "The Thermal Conductivty of Uranium Plutonium Carbides:" Trans. Am. Nucl. Soc., 12, 591 (1969).

4. S. Bocker et al. "The U-Pu-C-M Carbides," in Plutonium 1970 and Other Actinides, W. N. Miner, Ed. (The Metallurgical Society of the American Institute of Mining, Metallurgical, and Petroleum Engineers, New York, 1970) pp. 113-119.

5. J. C. Van Craynest et al. "Thermal Conouctivity of Mixed Uranium and Plutonfum Carbides, Nitrides, and Carbonitrides," proceedings of the 8th Thermal Conductivity Conference, Purdue Iniversity, 1969, pp. 587-601. 
6. R. Pascard, "Properties of Carbides and Carbonitrides," AIME Symposium on Plutonlum Fuels Tech-nology, Phoenix, Arizona, October, 1967, pp. 345368.

7. J. B. Moser and O. L. Kruger, "Thermal Diffusivity of Actinide Compounds," Proceedings of the 7th Thermal Conductivity Conference, Gatthersburg, nD November, 1967, pp, 461-467.

8. C. A. Alexander et al., "Thermophysical Properties of $(\mathrm{U}, \mathrm{Pu}) \mathrm{N}$, " in Plutonium 1970 and Other Actinides, W. N. Miner, Ed. (The Metallurgical Society of the American Institute of Mining, Metallurgical, and Petroleum Engineers, New York, 1970) pp. 95-103.

9. J. J. Caldwell et al., Eds.. "Quarterly Progress Report, April, May, June, 1968, Reactor Fuels and Materials Development Programs for Fuels and Materials Branch of USAEC Division of Reactor Development and Technology," Battelle Memorial Institute, Pacific Northwest Laboratory report BNWL-842 (August, 1968) pp. 5. 14-5.17.

10. Y. S. Touloukian et al., Eds., Thermophysical properties of Matter, Vol. 1, Thermal Conductivity, Metallic Elements and Alloys (Pienum Publishing Corp. , New York, 1970).

11. G. H. Golden and J. V. Tokar, "Thermophysical Properties of Sodium," Argonne National Laboratory report ANL-7323 (August 1967).

12. Y. S. Touloukian et al., Eds., Thermophysical Properties of Matter, Vol. 3, Thermal Conductivity, Nonmetallic Liqulds and Gases (Plenum Publishing Corp., New York, 1970!

13. Max Jacob, Heat Transfer, Vol. II (John Wiley and Sons, Inc., New York, 1957), pp. 3-4.

14. O, E, Dwyer, "Recent Developments in Liquid-Metal Heat Transfer," Atomic Energy Review, 4, 3 (1966).

15. M. G. Chasanov et al., "Chemical Engineering Divisioun, Reactor Safety and Physical Property Studies Semiannual Report, January - June, 1973," Argonne National Laboratory report ANL-8020 (June 1973), pp. 3-5.

16. B. A. Boley and J. W. Weiner, Theory of Thermal Streases (John Wiley and Sons, Inc., New York, 1960), pp. 288-291.

17. M. E. Meek and B. F. Rider, "Compilation of Fission Product Yields, Vallecitos Nuclear Center, 1972," General Electric Nuclear Technology and Applications Operation report NEDO-12154 (January 1972).
18. D. Stahl and A. Strasser, "Properties of Solid Solution Uranium-Plutonium Carbides," in Carbides in Nuclear Energy, L. E. Russell et al., Eds. (Macmillan and Co., Ltd., London, 1964) pp. 373-391.

19. J. G. Conner and S, W. Porembka, "A Compendium of Properties and Characteristics for Selected LMFBil Cladding Materials," Battelle Memorial Institute report BMI-1 900 (May 1968). 
APPENDX A

PINTEMP COMPUTER PROGRAM LISTING

LASL Identification: LP -0501

PHUGRAM PINTEMP (INP, OUT,FILM)

PHOGRAM CALCUIATFS IFHP DF A FUEL PIN IN EBRIII

FUFL PIN DESCRIBED BY CONCENTRIC CYLINDERS

REGION 1 ASSUMED TO AF A SOLIO CYLINDER

RE GINNS $2+$ ARE HOLLOW EYLINDERS

ONE OIMENTIONAL. REAT FLOW EUN SOLVED IN H DIRECTIUN FOR

VARIOUS $Z$ PLANES - ASSUMF AXISYMMETKIC

PLOMING SOOIIIM DUTSIDE PIN

FJSSION ENERGY GENERATION INPUT OR CALCILATER FROM U AND PU CONCENTRATION Gamma heATIRIG CALCULATED FOR EACH REgION

SPLINE INTERPIILTION AND INTEGRATION ROUTINES ISED TD CALCULATE.

AXIAL VARIATIONS

THERMAL STRFSS CALCULATED Ir. HULLDW CYLINDER REGIUNS

PLANE STRAIN CALCUL,ATIOR.

PHIJGAM CaLCULATES FISSION GAS GENERATED 10 GOAL BURNUP

IADEX NUTATION

$I=$ REGIOV T.NJEX

$M$ I MATERIAL INDEX

$K=$ RAIIIUS INTSEX

JI * ISSTUNATLF ISOTUPE INDEX RADI

Ji IXIAL LOLN INDEX FDH AF, AE, AND ZL

$J G=A X I A L$ LOEN INDEX FUR AG AND ZG

$J R=$ RON INDEX 1 TOO

$W I$ = A.R REGIONS

NM = NQ MATERIALS

IUK $=$ NR RAUII

MI = MAX NA REGIONS

$M K=\operatorname{MAX} N R K$

$H J I=N H F I$

NJL $=$ NA $J L$

I TR $Q$ NJR $=$ NR ROWS

$J:$ GENFHQL IUDFX

IRE = RAJIAL INDEX IN TEMP FOR AXIAL PLOT IHPM = TOTAL NH IN PLOT

$N \angle C=$ INDFX I: 7 PLAI:E LOOP $T Z T$ a COUNT OF NR OT $Z$ PLANES

DATA INPUT

EART) TITLE I CARO FURMAT LO

SET I HEAGEPROHI.EH PITLF COL IOBE

EARD GENERAL PROBLEM VATA 1 CAHD FORMAT LS

SET $Z$ NIOA, RADIAL AFGJGNS

TPI B.CORE LOCATION

ZP?=:OCATTIME IN SUBASBEMHLY

NOL = JENO AXTAL PLOT FIOAXIAL DLOT

NFF $=1=$ CALC FISSION ENEKGY GENERATION FROM FUEL CRMPJSITION $=2=I N P I T A X I A L$ LOCN $A N D K W / M$

NAEO=NO THFRMAL F DARSION CORRECTION OF RADII

$=I=$ COHHECT RADII FOH THERMAL EXPANSION

LBF $=L$ DCN DF SOTTUM OF FUEL STACK FRAM CURE MIDPLANF CM

ZFCL =INTAL FUEL COLUAS LENGTH CM

DNAE JIILK SOIUUM FLON HATE AT INLET CC/SEC

ACAAEOUDIUM FLON TATE GHEA COMSO 
DNA = S.SUIV OIAM OF SODIUM FLOH CHANNEL CM

TAA $\triangle$ BUDIUM INLET TEMP C

NSAE TNDICATIR FOR S/A FLOW FIATA CALC

=1IEUSF ONA, ANA, ONA AS REAL IN

$=1$ ICLAC FUR AN AO19Y S/A INPUT FGPM

=2=CALC FOR EO29 OR NO19 S/L SPECIFY MTP ANO FRDA

ATPEPIN LACATIUIA IN EMIO OR NOIN S/A

$=I=C E N T F R$ PIN

$\approx$ ZEE DGE PIN

$=3=C O R H E R$ HIN

FGPM=TOTAI. S/A FLOW RATE IN GPM

CARD HEGIJN OATA NI CARDS FURMAT 29

SET 3 NR(T)=REGIDN NIJMER

RNMCI $=$ EREG I ON NAME

MUT TI IREGIOR: MATERIAL NUMBER

RS (I) =OUTSIDE RAOIUS OF RF.GION CM

NRC (1) $=N R$ OF RADII TO CALC TEMP ZOJNSIOE AND OUTSIDE SURF DNLY

NRPL $(I)=U=S U R F$ TEMP NIT IN AXLA' PLNT

$31=$ INCLIJTE SURF TEMP IN AXIAL PLOT

PTD(I) =PERCENT THE RRETICAL OENSITY OF REGION

NST (I) $=G=D N$ NUT CALC THFRMAL STRESS FOR THIS REGION =I IEALC TMERMAL STRESS TN REGION AT SAME RADII AS TEMPS

PEAC (I) $=$ PERCENT HOLES (NA) IN IIRER IF MN(I) $=5$ =PERCFNT HE IN GAS BOND IF MN(I) $=8$ ON 10

CARO PFAK GAMBA HEATING FOR EACH MATEKIAL I CARO FRAMAT 35

SET 4 DGWG(H)EPEAK GAMMA HFATING W/BH MEI,NA

CARO FISSION FNFRGY GENERATION DATA

SET 5 TYPE OF DATA AND FORMAT OF CARC SET 5 OEPENUS ON NFE

IF NAE $=1 \quad 2$ CARDS

FlKST CARA FORMAT SS

NAFE = HFGINA NH WHERE FISS ENERG GEN

NFEA $=S P A R E$

NUSWEIGHT PFRCENT WRANIUM

HPUEMEIGHT PERCENT PLITINIUM

LI2355, NEIGHT PFRCFNT L235 IN $U$

U233=WE. IGHT PERCEAT U233 IN $U$ U238=100-U233-U235

PUZ39=WElGHT PERCENT PUZ39 Jh PJ

PUPUDIWEITMT PERCENT PUZ4U IN PU

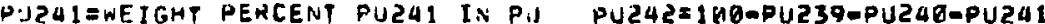

BUMX $=$ GOAL DIIRNUP MAXIMUM AIIIM PERCENT

SECONIT CARD FUHMAT SS

$F(I T)=P F A K$ FISSION RATE FISS/SEC GM FUR FISSIONABLE ISOTOPES U235,L:2S8,PU239, AND PIJZUO

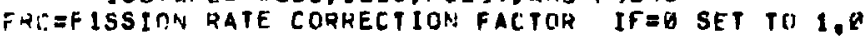

IF NFE=2 ? OR MDRE CARDS

FIRST CARD FORMAT 73

NRFE =REGION NR WHERE FISSIUN EPIEHGY GEN

IANZ =AR OF ZFE, OFE PAIRS TO BE INPUT

SECOND CARD(S) AS MANY AS REQIJIRFD FORMAT TS

LFF $(A Z)=A X$ IAL LUCN FROM BOTTOM OF FICEL CM

FIHST ZFE MLST GE ZERO TO ALLON INTFGRATION FRUM D TOZ

LAST IFE MUST BE FUEL COL LENGTH TI ALLOH CALC OF OUTLET NA TEMP UFE $(N Z)=K K / M$ AT ZFE $(N Z Z)$

NZ:1,NNZ

CARO L PLANE DATA UP TU SO CARES ALLOWFD FORMAT IIL

SET 6 ZLLUCN UF $Z$ PLANE FRGM HOTTRM OF FUEL 


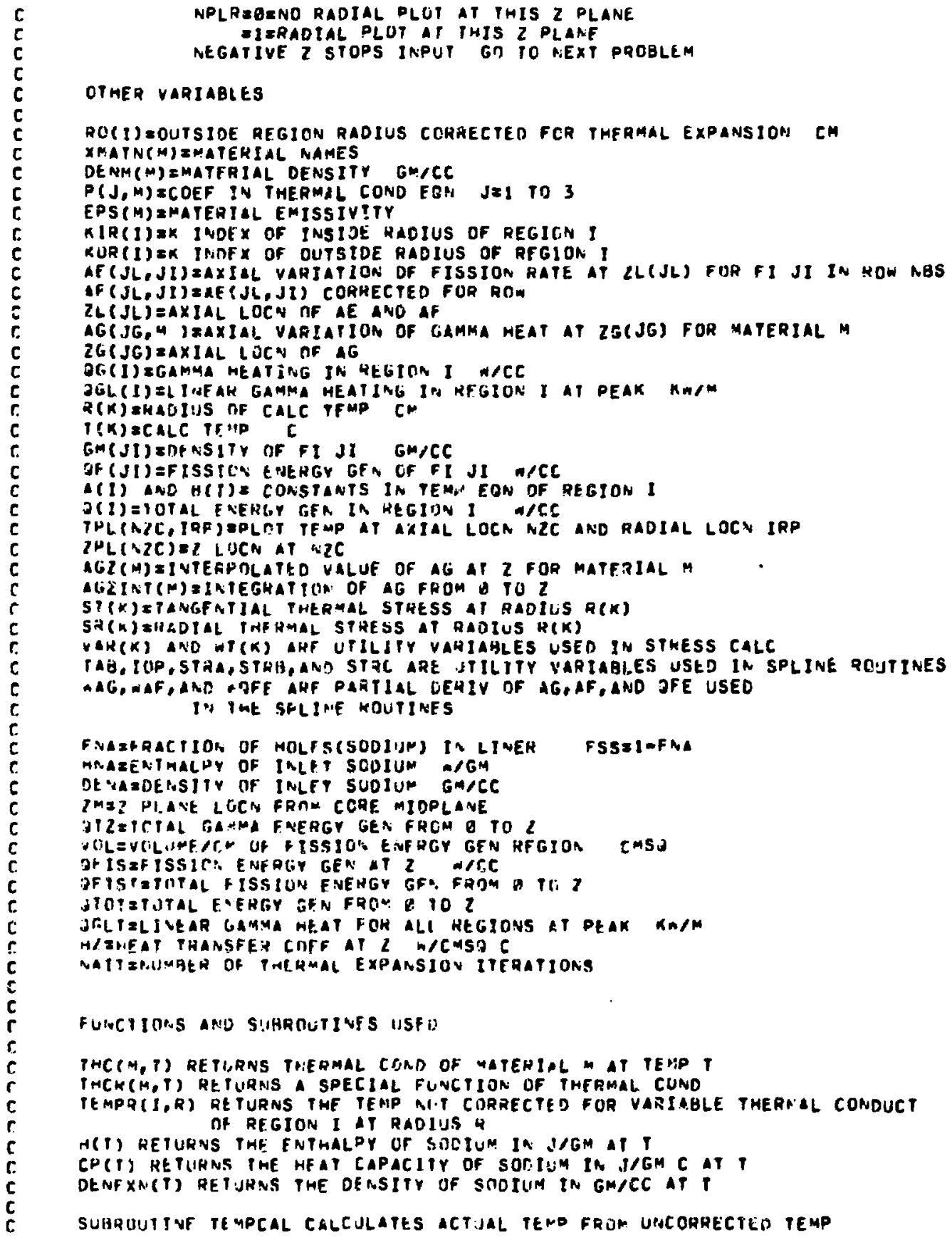


SLAHOUTINE FISGaS CALCULATES THE FISSION gas PRODUCTION AND EHR-II MAD AI GMAL BIRNUP

PARAMETFK (MI $=10)$, (MK $=50),(N M=10),(N 3 I=1),($ MZZ $=26)$,

I (NJL $=28),(N J R=9),(M I 2=2 * M I),(N J G=2 B)$

$c$

DIMENSIOM HEAD(B), NR(MI),RNM(MI), MN(MI), RO(MI), NRC(MI),EG(MI)

1, MRPL(MI), R(MK), T(MK), F(AJI), GM(NJI), OF(NJI) FINM(NJI)

Z,7FF(MNZ). EFE(MNZ), TAB(3),PERC(MI), A(MI) H(MI) O O(MI)

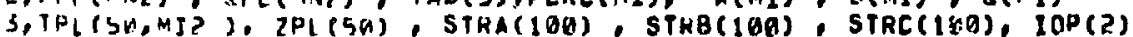

4, RTE:MI), KIF(MI), KOK(MI), EPS(NM), RS(MI), ALFA(NM), GGL(MI)

DIMFAS [ONA XMATN(NM), P(3,NM), OGNG(NM) DENM(NM),PDD(HI)

OIMFNG IOU AG(NJG,NM), AF (NJL,NJI),PA(NJK,NJI),ZL(NJL),ZG(NJG)

1. NAF(NJTI,NM), WAF(NJI,NJI), MGFE(MNZ), AGZ(NM), AGZINT (NMS

S. At (NJI, NIJ)

DIMENSION XIITK(2), XIITZ(S), YTITL(2), PLANE(5), CRVNM(19)

U]MEVSJIIN SH(MK), ST(MK), VAR(MK), NT(MK), HSI (MI)

COMMOA /DATA/P

CCUNUN/DATB/A, B, RCL, RO, O, MN, PTO

CUMB OANOATC/REM,HS

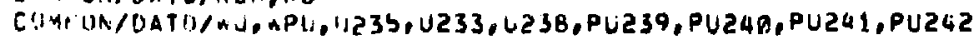

CUMGUNJUATE/F,PA, BM

FUNCIION DFFINITIONS

SUIIUM ENPHALFY FXA JOULF.S/GM (HEF ANL-8DZO)

$H(T H)=(A .88 I 45 *(T H+273 . H)+(1.39635 E-4 *((T H+273.0) * \star 2))$

$1-(8.97824 E+5 /(T H+773.0))+97.6345$

DFRIV OF SOOTJM ENTHALPY FXI

$C P(T H)=0.88146+(2.74271 E-4 *(T H+273.0))$

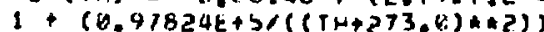

SIOUIJM DENSIIY $F \times M$

RESULT I GMFCC RFF ANL-7323

DE NF XN(TH $)=(59.566-(7.95 \% .4 E-3 *(1,6 * T H)+32.0))$

$1-(A .28 T P E-6 *(((1, \theta * T H)+32.0) * 2))$

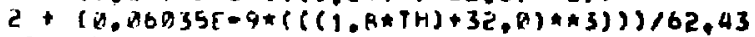

E*ALFA FUNCTION FCR $316 / 3 H A$ STALNLESS STEEL RESULT IN PSI/C

RESULI DIVICED SYY IOPDISSCINS RAIJO E.T FOE PLANE STRAJN CALC

EALFA(TH) $=(476.0937)+(0.14433541 * T H)=(1.9554452 E-4 * T H * T H)) / 0.7$

NATERTAL DATL

MATERIALI $1=(1, P U) C$ FUEL

MATERTAL $?=(H, P L I)$ R EUEL

MATERIAL $3=3+4 / 316$ STAINLESS STEEL

MATERIAL $4=$ SUDIUM

RIATERIAL. $\zeta=$ LINEH TUAE COMPASED FROM SS AND SQDLUM

MATERIAL $6=$ TELIUM GAS

MATEHIAL 7 = FISSION GAS

MATEHIAL $8=$ HELTUM-FISSION GAS MIXTURE ONLY I PER PHOBLEM

MATHRIAL 9 = RADIATION CONOLCIOH FUR USE WITH MATERIAL IO ONLY

MATERIAL $10=$ HFLIUMAFISSIOL. GAS MIXTURE MITH RAOIATION ONLY I PER PROE

OATA FOH HATF'RIALS 5 , H, ANG IN CALCULATED AT REGION DATA INPUT

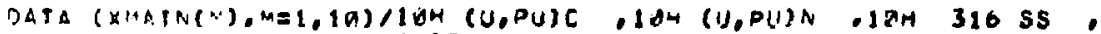

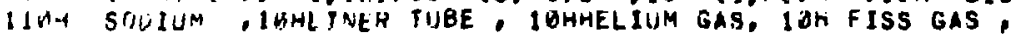

2) WHHF +F (: $M I X$. I HH HAN COND, IDHHE +FG+RAD

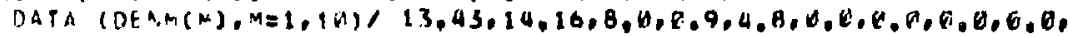

in, 0,

DATA (BGNG(A), 4*1,1n) /10*0,A)

i) IA (EPS (M), $n=1,1,1), 6,5,4,5,0,2,0,1,2,2,1,7,1,6,1,4,1,0,1,01$ 
DATA :ALFA(M), M=1, $\{01 / 1,2 E-5,9,95 E-5,1,85 E-5,0,0,1,85 E-5,0,0$, $10,0,0,0,0,0,0,01$

DATA $(P(M), M=1,30), 0,12714271,1,0613922 E-4,-2,7972363 E-A$,

$10.12521091,7.2282857 E-5,-2.0326063 E-B$.

$29,83832746,1.5676010 E-4,-1.4457896 E=9$.

3 . $91824191,-5,3734757 E-4,8,1783766 E-B$.

4 月.

$51.4936968 E-3,3.0626658 E-6,01.6875619 E-12$,

6 $0.73209979 \mathrm{~F}-\mathrm{A}, 1.25 \mathrm{~A} 107978 \mathrm{E}-7,-1.105792494 \mathrm{E}-11$.

$70.90,0.0,0.0$.

$32.5621967 E-2,-9.3672545 E-5,1.1247254 E-87$,

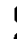

$90,0,0,0,0,0$,

RELAIIVE AXIAL GAMMA HEATINC

FUEL 1

DATACAG(JC), JCE=1,5A), $2(0,65,0,15,0,77$,

$0,75,0,73,0,78,9,85,0,88,0,93,0,95$

$20,82,0,72,0,64,0,74,0,71,4,70,0,66)$,

C

STAINLESS STEFL

DATACAG(JG),JG=57,843/ $0,20,0,30,0,44$,

$0,54,0,64,8,74,6,81,0,875,0,925,0,950$.

$10,975,0,990,0,998,1,93,0,999,8,995,0,985,0,975,0,950,0,92,0,87$,

$23,82,0.75,0,63,0.01,0.46,0.35,4.26$,

C

SOSIJM

DATA (ACS(JL), JLEAS, 112$) / 28 * 1.4$,

C

DO 1 UPG $M=5, T .4$

DO $6 J G=1, N J G$

G $A G(J(j, M)=A G(.3 G, 3)$

1 MUO CONTINUE

C AXIAL LOCA OF AG DATA

DATA $\left(2 G\left(J(6), J G=1.2^{2}\right),-21.431,-19.717,-18.402\right.$,

$-17,16,-16,288,-24,573,-12,859,-11,144$,

$2-9,430,-7,715,-6,091,-4,286,-2,572,-8,85 \%, 8,857,2,572,4,286$.

$36.441,7,715,9,434,11,144,12,059,14,573,16,788,17,16,18,092$,

$419,717,21.4311$

RELATIVE AXIAI. FISSITN RATE

RELATIVE AXIAl. FISSINV RATES WERE ESTIMATEN OUTSIDE OF THE CURE REGION BY A CONSERVATIVE DIRECT EXTRAPQLATION FROA THE ENDS.

J235 AND $: 1233$

DATA (AF (JL), ,IL=1,56)/2(0,941,4,927,0,913,0,898,0,884,0,876,0,891, $14.916,1.934,0.958,0.976,0.967,0,997,1,00,0,999,0,991,0,902,0,968$.

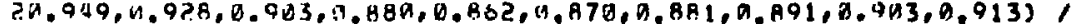

c $\quad 5238$

DATA (AE (JI), J(=57,B4)/ $1,290,0,348,0,400,0,534,0,618,0,715,0,788$,

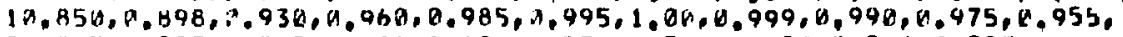
$20.925,0,887,0.855,0.780,0.680,0.570,0,504,0,420,0.368,0.227$,

$c$ PUI 339

DATA (AE (JL), JL=85,11?)/9,892,0,874,0,85H,0,842,0,832,0,840,0,870, $10,899,10,927,0,950,0,970,0,985,0,996,1,00,0,999,0,993,0,981,0,963$, $20,943,0,918,0,883,0,852,0,825,0,816,0,328,0,845,0,062,0,881$;

c PU240

DATA (AE(JL), JL $=113,148) / 0,42,0,468,0,518,0,620,0,660,6,742,0,810$, $10,860,0,907,0,940,90,969,0,987,0,995,1,60,8,999,0,972,0,975,0,955$, $20.925,0,890,0,850,0,797,0,730,0,655,0,605,0,566,0,524,0.442 ;$

SET PUZ41=PUZ39 ANR PUZ4ZXPUZ4B

DO $7 \mathrm{JL}=1, \mathrm{NJL}$

AE $(J L, 6)=A E(J L, 4)$ 


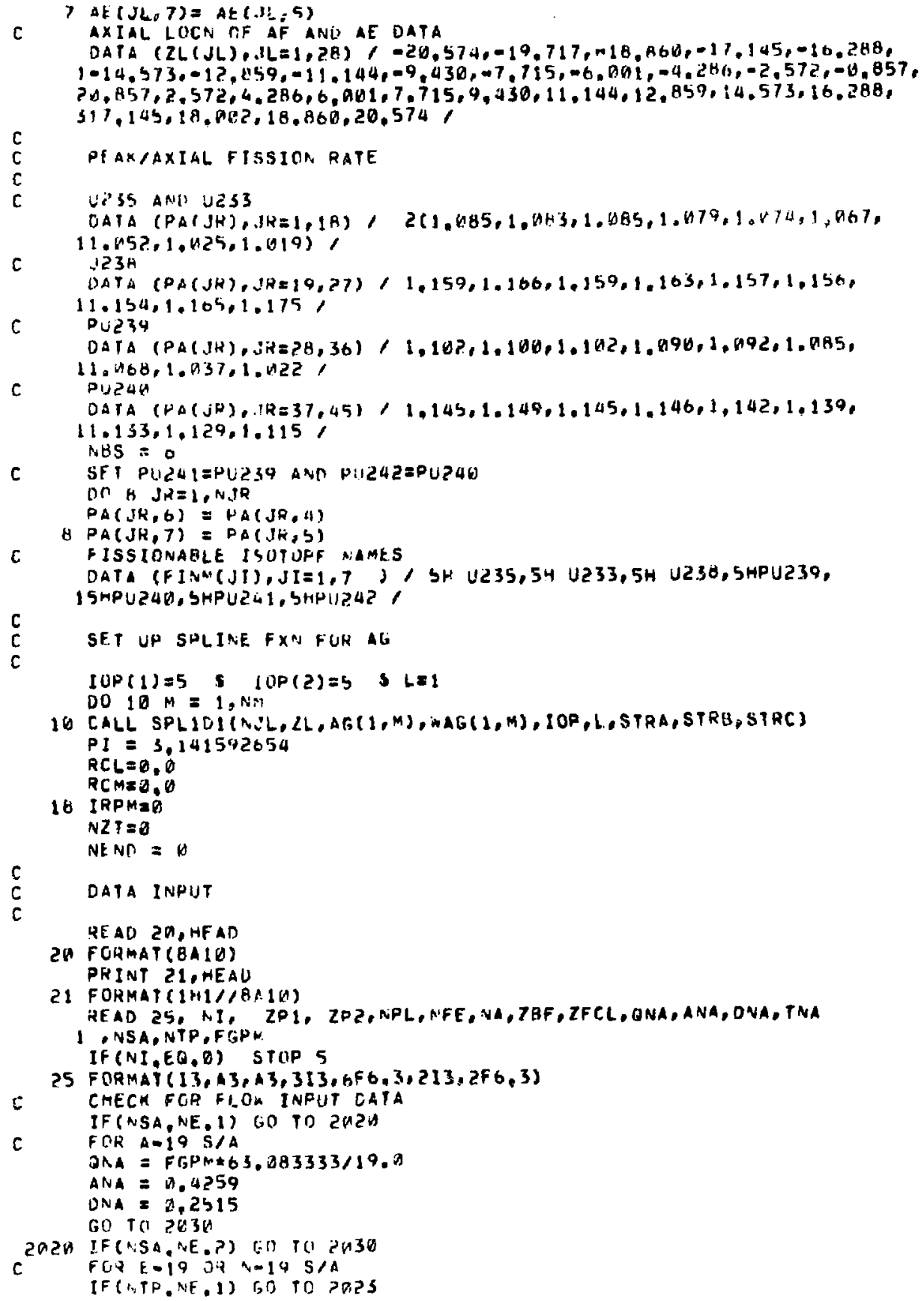




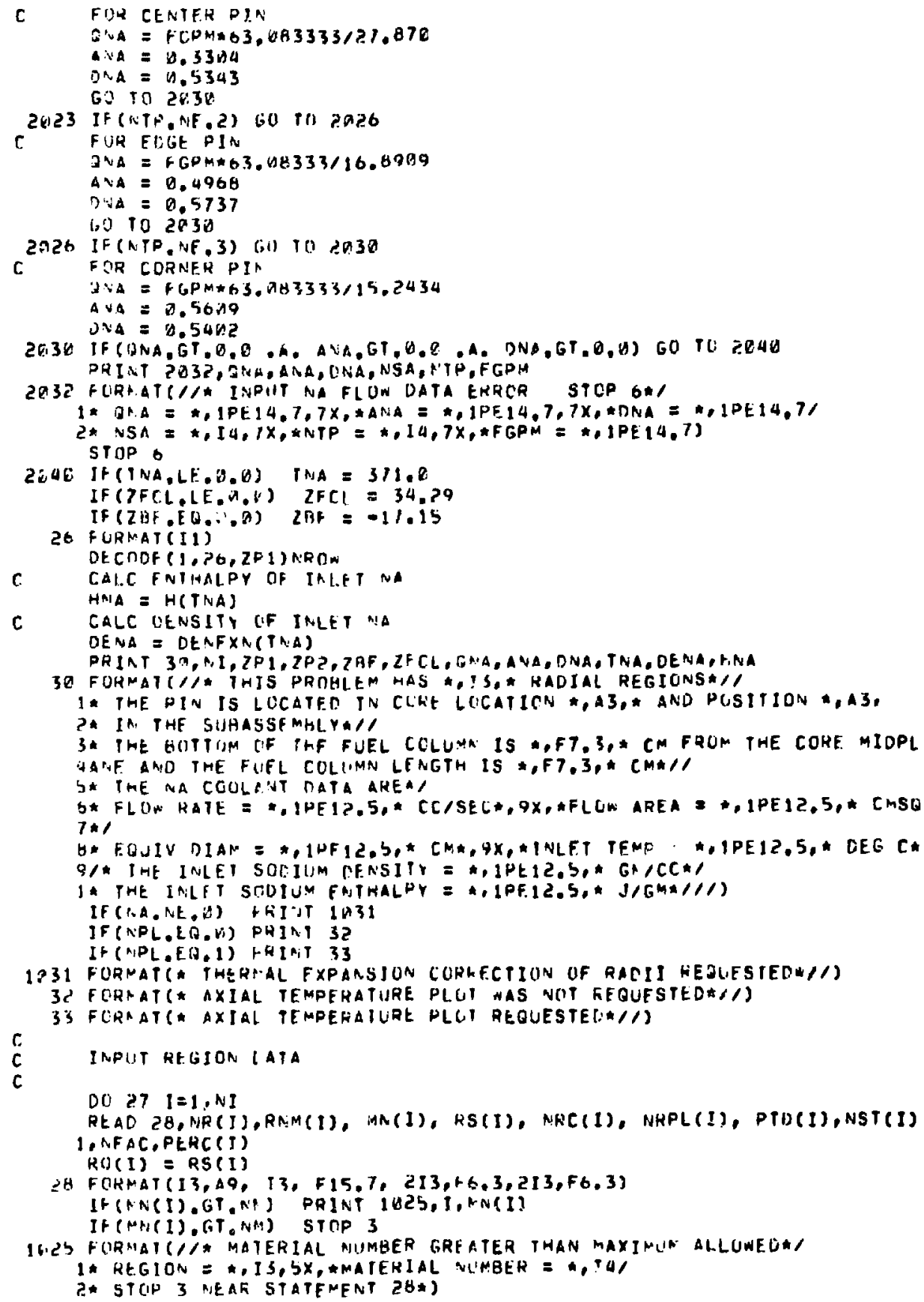




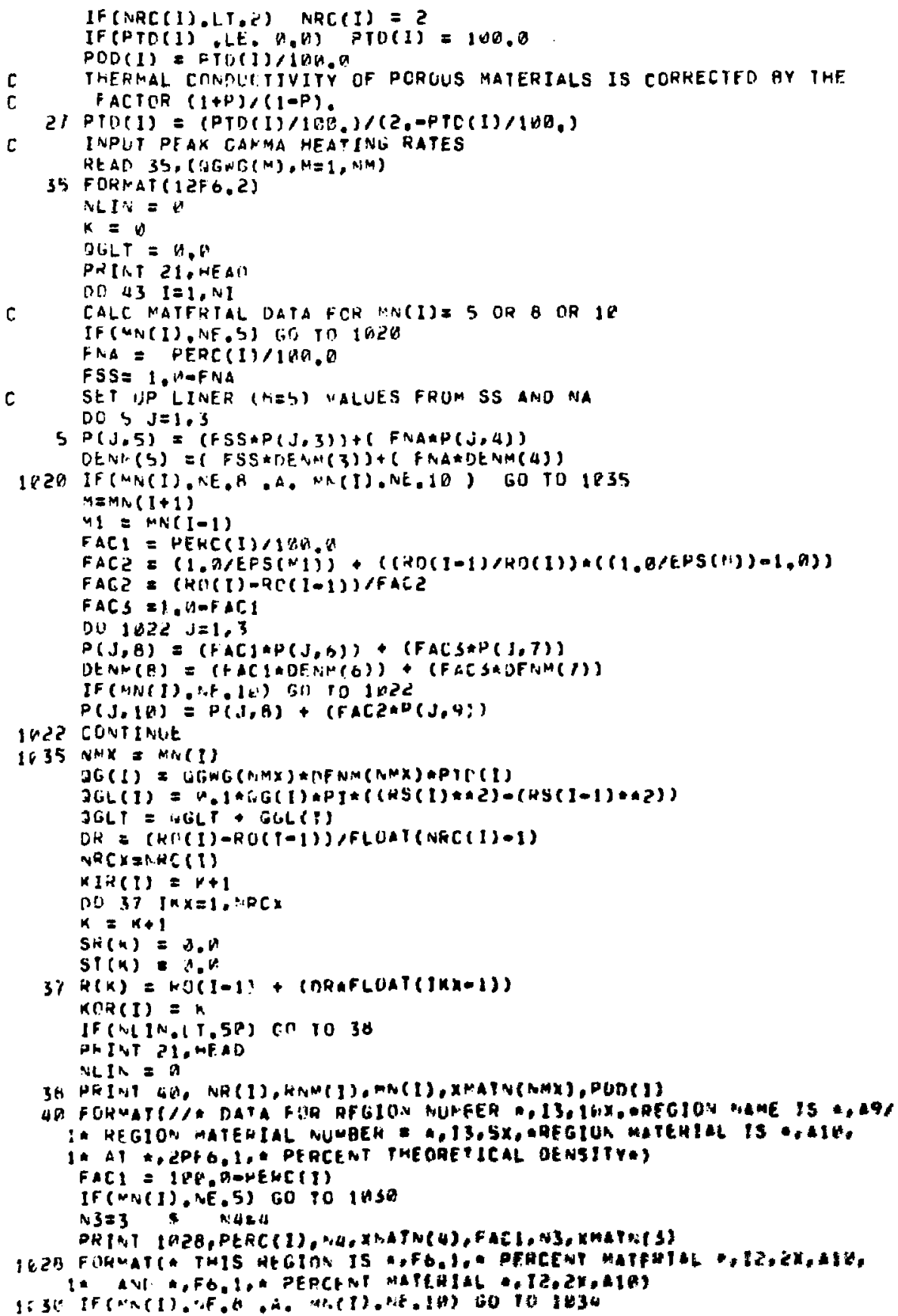




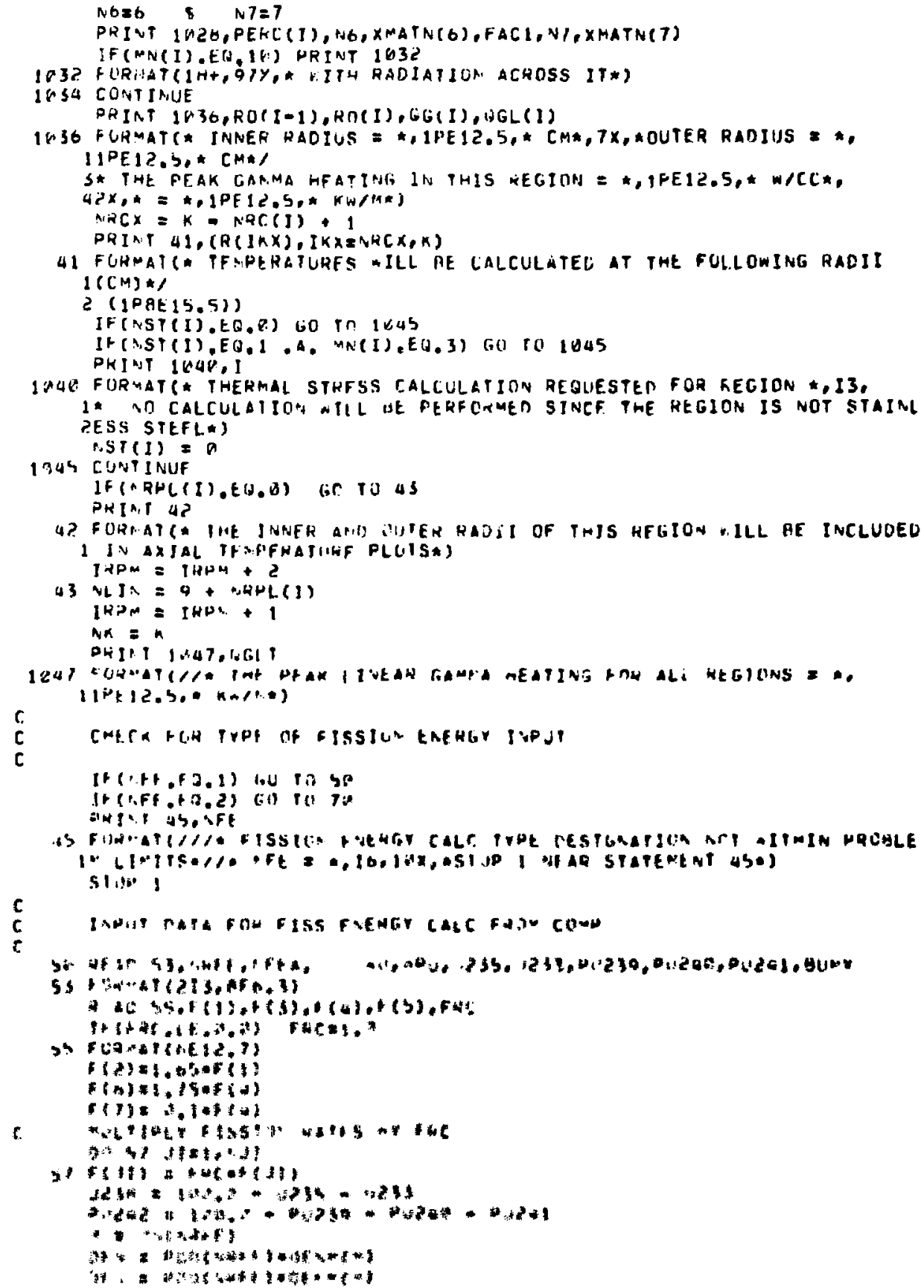




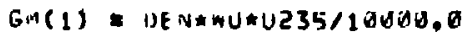

GM(2) = DENAMUU233/180BD.0

$\operatorname{GM}(3)=D E N * W U \# 11238 / 190 \cup B .0$

Gio $(4)=D E N * W P U * P(1239 / 10000.0$

GY(5) = DENAWPUAPUZ4G/1AGUA, G

GN(h) = DEN*APUAPIJZ41/1DOUD.G

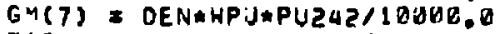

$F A C_{1}=196,0 * 1,602 E-13$

(i) ho JI $\mathrm{H}=\mathrm{N}$, NJI

bil JP $(J I)=F A C I * F(J I) * G M(J I)$

$001457 \mathrm{JI}=1, \mathrm{NJI}$

$F B=(1814 * S O R T(1.0-(1.0 / P A(N E S, J 1))) / 2.54$

$F A H=B .1814 *$ SIJRT $(i . B-(1.0 / P A(N R O H, J I))) / 2.54$

DPI 1 GS5 $J L=2, N J L$

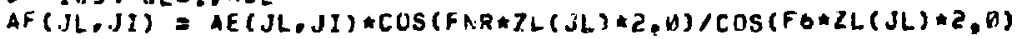

1755 CUNTINUE

1 AST CUVIIAUE

C SET UP SPIINE FXN FOR AF

$301060 \mathrm{JI} I \mathrm{i}, \mathrm{i.J} 1$

1260 CALL SPLIDI (NJL,ZL, AF $(1, J 1)$, WAF $(1, J 1), I O P, L, S T R A, S T R A, S T R C)$

PRTNT 21 , HEAO

PKINT G2, NKFE, I)EN, WU, NPU,U235,U233,U238,PU239, DU246, PU241, PU? 42

20 FORMATC//. FISSITN ENERGY GENERATION IN REGION *I3* CALCULATED FR IOW COMPOSITION*I

2A DEASITY = ,F7, 3,* GM/CC*,7X,*WI PERCFNT U = F,F, 3,7X。

SWOT PERCENT NU $=\$, F R, S I$

4* URANLUM ISOIOPIC CONTENT\#/

马* U235 $=\ldots, F 8,3,7 x, * \cup 233=*, F 8,3,7 x, * \cup 238=\ldots, F 8,31$

G. PLUTUNIUM ISOTOPIC CONTENT\#/

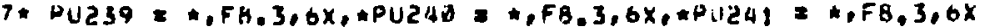

$4 . P U 242=\pi, F, 3)$

C CALC VOL ANIJ HEIGHT OF FISSION ENERGY RFGION

$\checkmark F, J_{i}=Z F C L * D=((K S(N R F E) * Z)=(R S(N R F E-I) * * ?))$

$\neg F I L=V F U L * D E V$

PHIAT 1HGS, NRFF, VFILL, WFUL

IOBS FIGIATIC CALC:ILATEO VOIUME AND WEIGHT OF REGION \#,I3/

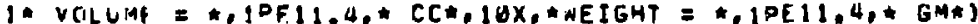

DAIVT 63 , FHC

a F FAMATINA IDPUT + ISSION RATES MULTIPLIFE HY CORRECTIUII FACTOR = *

$1,(8,5)$

DAT in ou

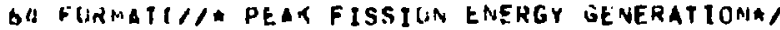

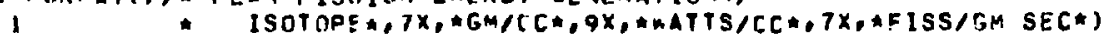

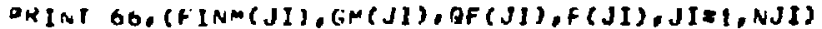

66 FURPA: : 4X,AS, 5X, IPF $11,4,5 X, 1 P E 11,4,5 X, 1 P E 11.49$

c

CALIULATE PEAK AND AVFRAGE LIREAR PONER AVD TUTAL PONER

PACZED.H S PACSEB.U

Du idgi $J I=1, n J I$

HACZ E FAC2 + OH(J)

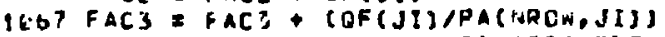

$F A C I=P I *($ (RS (NRFE) $* 2)-($ AS $(N R F E-1) * 2\})$

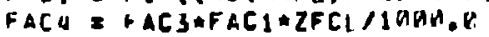

FAC? = FAC 2\#FAC1/13.H

FAC 3 = FACSAFACI/19,3

DKIAT 1 OOBO, RRFE,FACZ, FACS,FACA

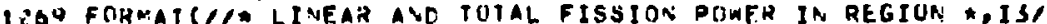

1. PKAK LINEAR PUAER M AFB,3, KW/M*I

2. AXIAL AYERALF LINEAR POWFR $=4, F 8,3, * \mathrm{KW} / M \star 1$

3. IRTAL PONER = *,FB,3, NAW]

It (HUIMX,LF. B. (I) GO TO 90

PQI'I 2I, HEST

CAI FISGAS (A,HOA, HFUL, IFCL, BUMX, VFUL) 


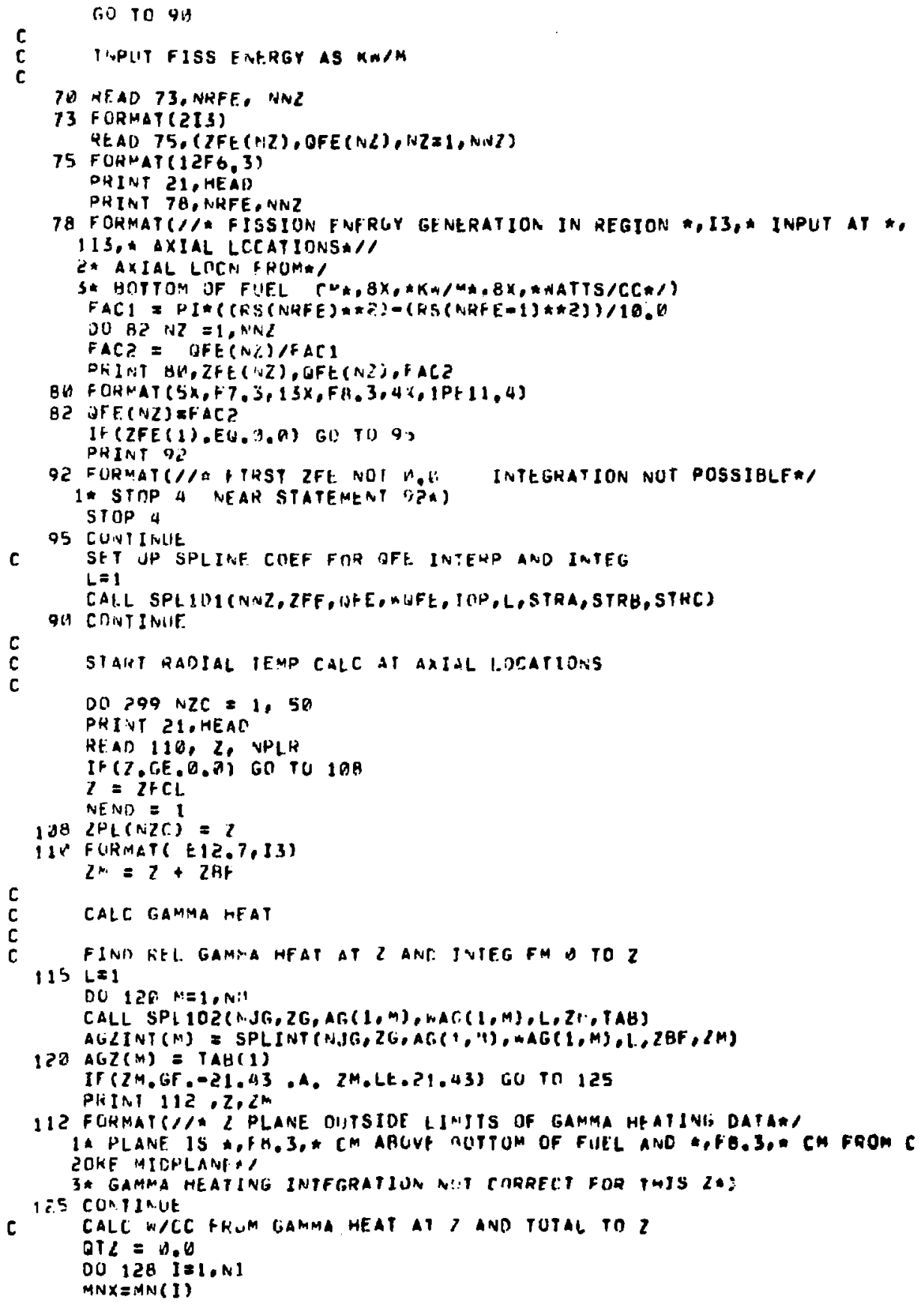




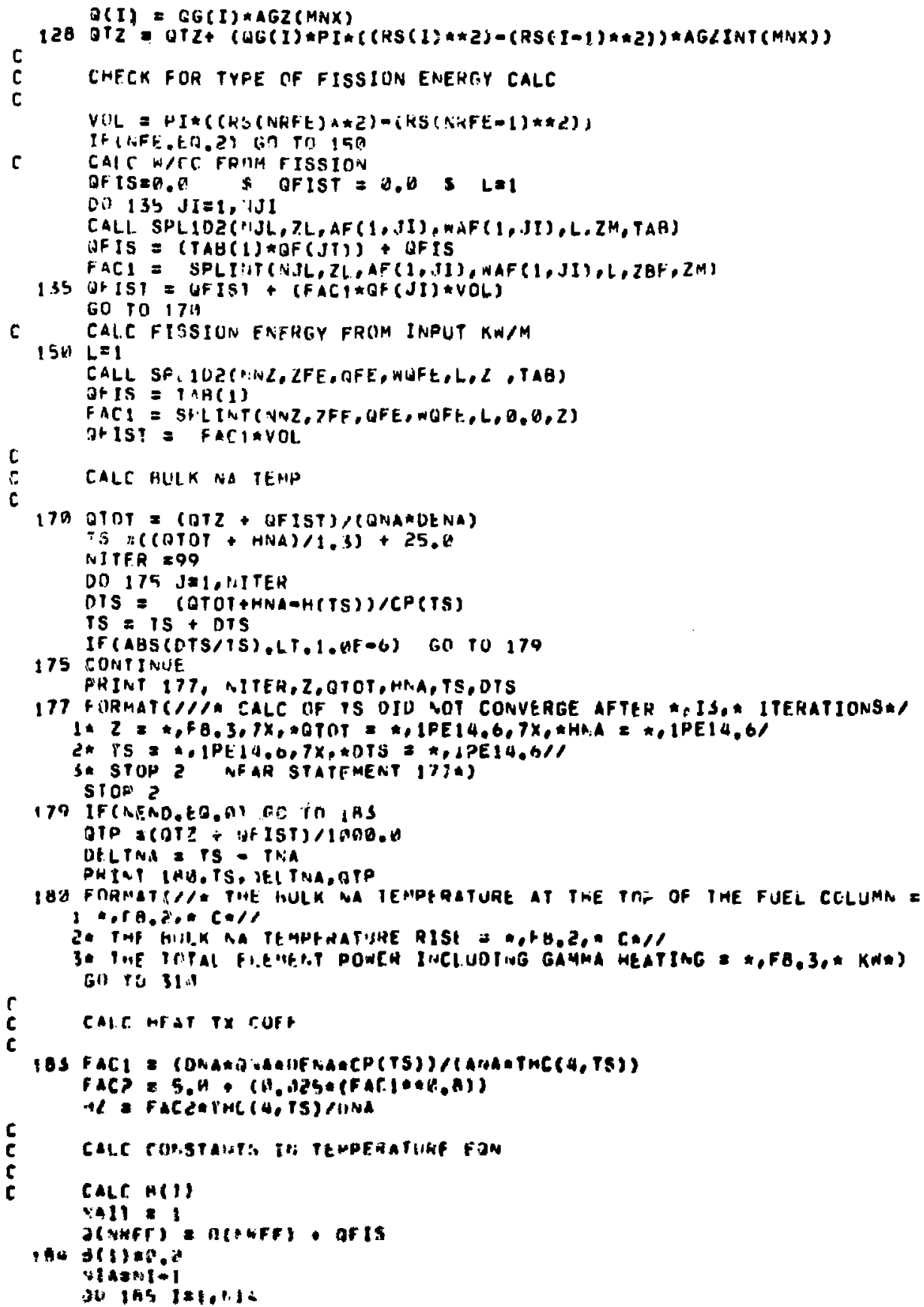




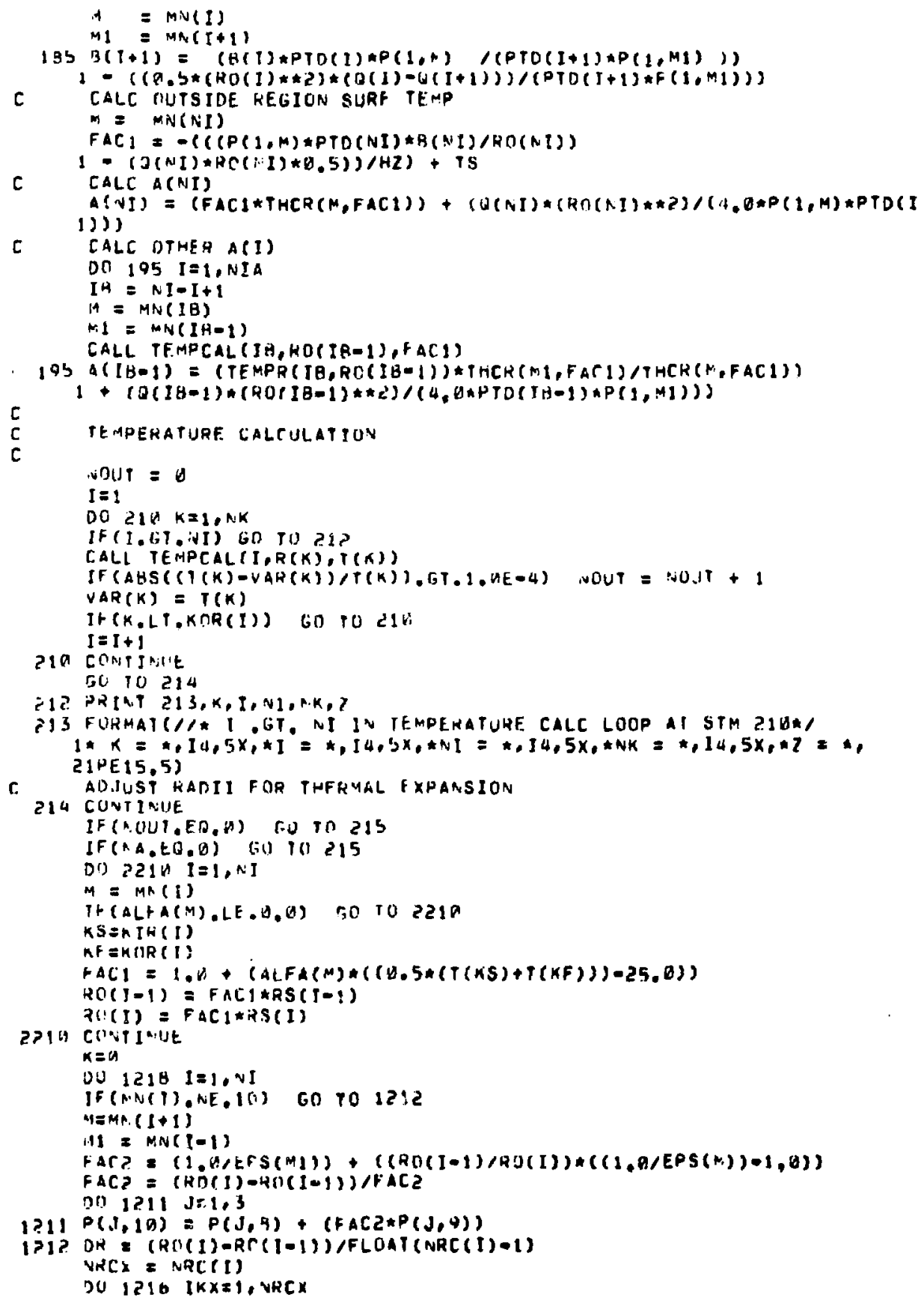




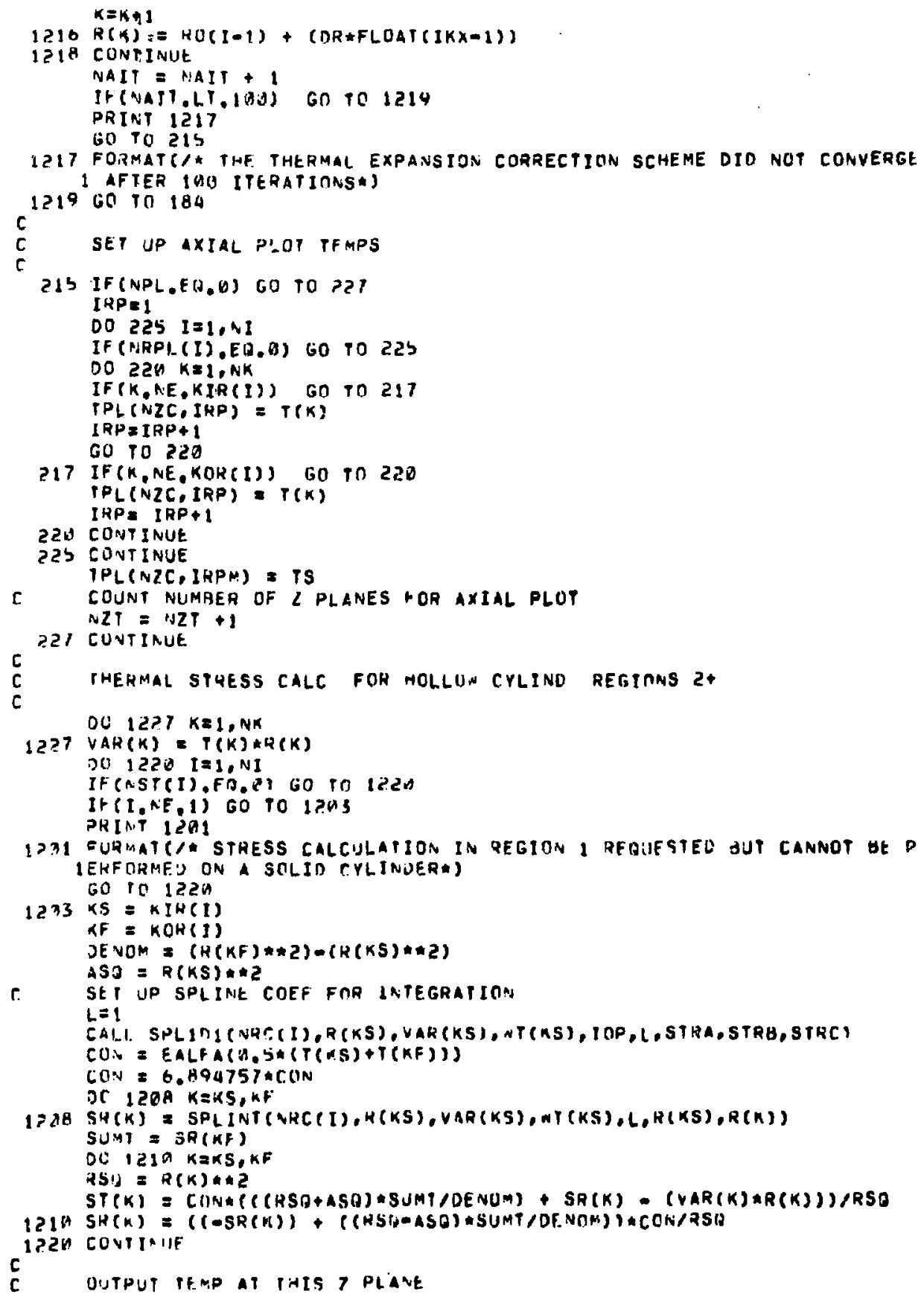




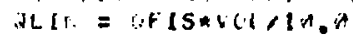

229 PRIMT 23U,Z,ZM,TS,HZ,OTOT,OIIN

33) FURMATI/* RADIAL TEMPERATURE VARIATION AT $Z=4, F 7,3, *$ CM ABOVE IH IE HOTIOM OF THE FUEL COLUHN $=*, F 7.3, *$ CM FROM THE CORE MIDPI.ANE* 2/\% THE BULK SODIUM TEMPERATURE $=\star, F B, 2, * C *, 5 x_{0} \star T H E$ MEAT TAANSFE 3R COEFFICIEMT = A,JPEI2, H, HICMSO CMI

4* THE ENTHALPY INCREASE OH THE BULK SODIUM = *,IPEIZ,4," J/C,RA, 41 $2 X$, , THE LINEAR FISSION POHER = $*, O P F B, 3, * \mathrm{KW} / M * / 1 /$

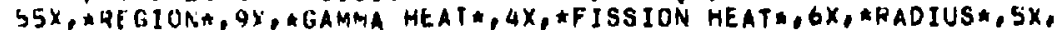
6*1EMPERATURE, $12 x_{0} *$ THEHMAL STRESS KPA*/

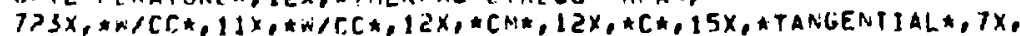
$h * R A ! I A L * /]$

$I=1$

DO $23 \% \quad K=1, N K$

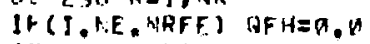

IF I I, $Q$, NRFE) OHHEDFIS

IF( . FQ.KTR(1)) PKIAT 235, IVA(1), RNM(I),O(1), DFH

PHI I. 23 S. H $(K), T(K)$

IF (..ST(I), FO, I) PRTH:T $232, S T(K), S R(K)$

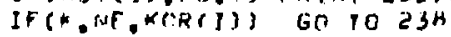

$I=1+1$

PhINT 256

ise CUNTIR.UE.

IF (A.A, NF,OS PAIVI $237,1 . A \perp T$

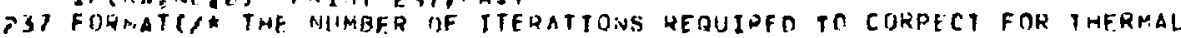
1 EXDAASINH $= \pm,(3)$

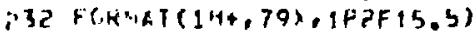

; $33 F$ FRAI (45X,JFF 15, 4, 4X, UPF $A, 2)$

235 FISTAT $(1 \times, 13,2 \times, A 9,1 P P E 15,4)$

336 FOAHAT (IH)

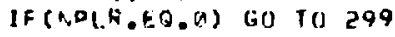

$\mathbf{c}$
$\mathbf{C}$

RAOTAL IERP PLCI

DATA YBT,XLP, XQR, $1.0,0,0,0,5$,

UAIA IXL,IXH.IYT,IYí, IS:, 986, SH, 919 ,

$Y T P=16,1(4,0)$

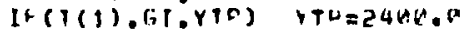

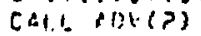

CAI.L FHAMF ( [XI, IXII, IYT, TYIS)

CAI LGACIXU,IXF, IYT, IYA, XLA,XRH, YTP, YBI)

NXIAT=1 \& BYTNTEA

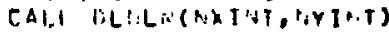

Axisis

$x Y \mid)=.1$

$x \times n=1$

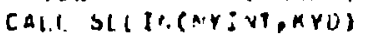

CALI Stil IP, (PXI:!T,KXI)

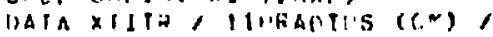

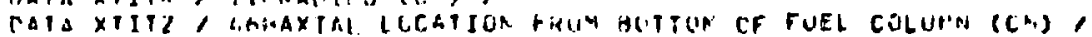

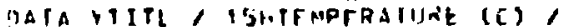

CiATA PI A.UE/SHBL PIART =

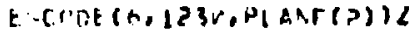

$12 \operatorname{sil} 6[\omega, 4:(F 6,2)$

(1) $1235 \quad i=1,1.1$

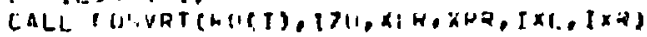

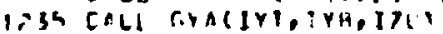

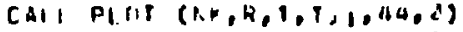

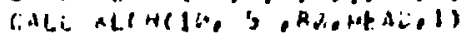

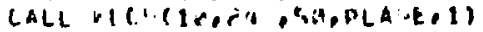

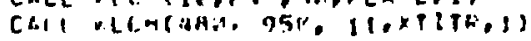




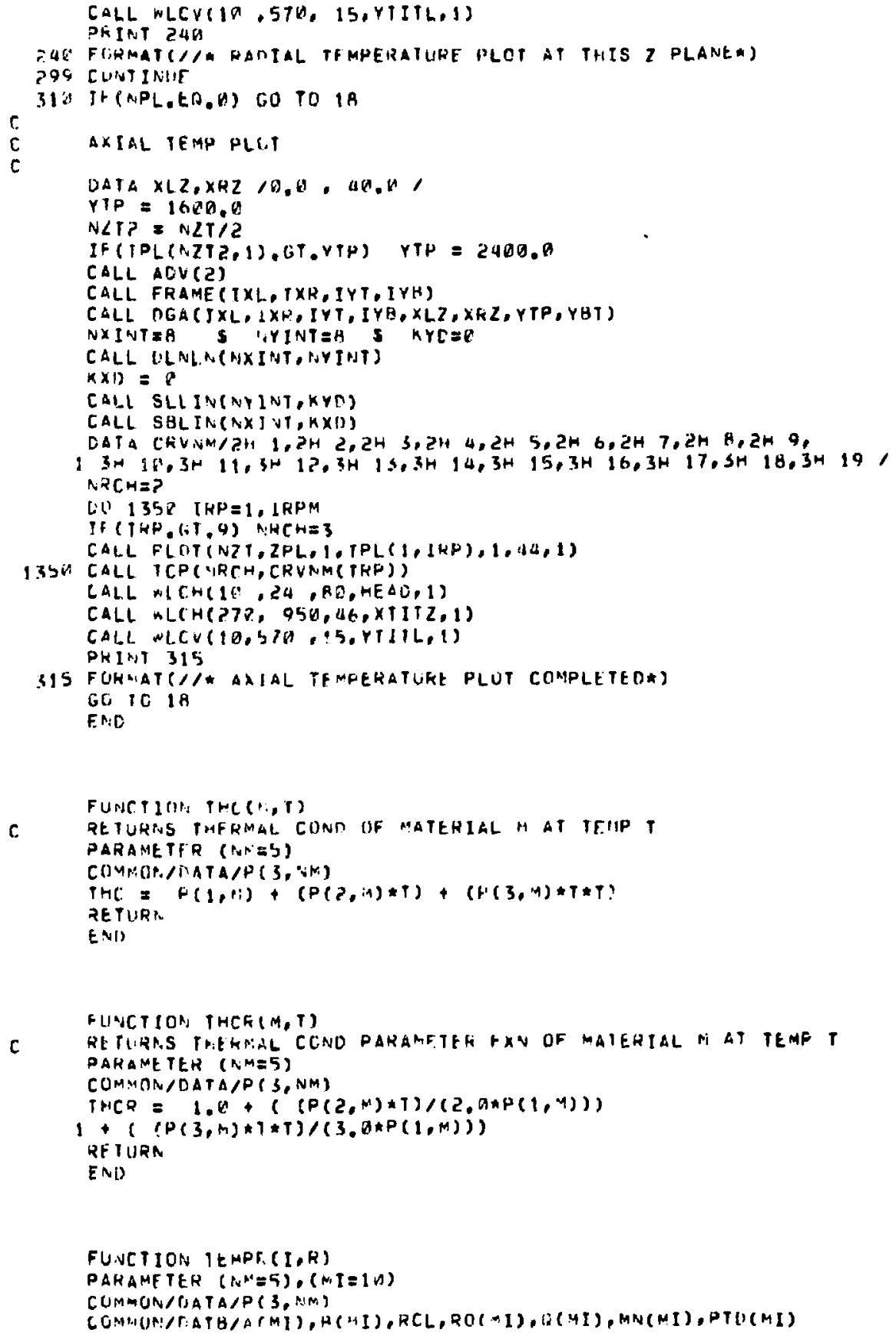


$M=M(N)$

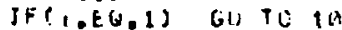

TEIPR $=A(I)+(G(I) * A L O L(A / R O(J)))=(Q(I) * R * R /(P(1, M) \star P T D(I) *$

14. A)?

RE TURN

16 IEMFR $=A(1)-\left(Q(I) * R * A /\left(P\left(1, B_{1}\right) * P T D(1) * 4,0\right)\right)$

RETUAN

EN?

SUBROUIINE TEP.PCAL $(T, R, T)$

PARAMFTER (NATE), $(M)=19)$

COMMUN/LATA/P $(3, H M)$

COAMUR, PIATIB/A(MI), B(NI),RCL,RO(MI),B(MI),MN(MI),PIT(MI)

$M=M N(I)$

CUN $=\operatorname{TEMPR}(I, R)$

$T_{H}=\mathrm{CHA}$

Do $18 \mathrm{~J}=1,3$

10 TiS = CON THCK(M, TN

DU) $20 j=1,25$

IC $=$ THCR $(M, T H$,

DiN $=(C O N-(P N * T C)) /(I C+(1 N+((E, 5 * P(2, M) / P(1, M))$

$1+(2, D * P(3, N) * T N /(3, n * P(1, N)))))$

$T N=T N+D T N$

IF (ABS (NTM TN) LT 1, AE-6) GC TO 33

2 G CONTJAUE

PNINT $22,1, F, P, D T N, T N$

?2 FOHMAT(//\# TERPCAI DI' NOI CONUERCE ON A TFMPERATUREA

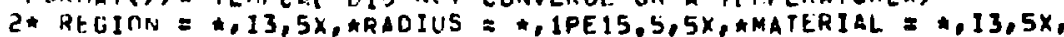

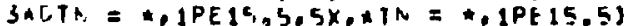

RE TURA

$361=T N$

RE TURP:

END

SUBRDI,T I INF F ISGAS(NR, W, FCL, HMAK, VQL)

PARAMFTER (NI=7), ( $J=(B),(A J H=9)$

CIMENSION Y(NI,NJ), F(NI), PA(AJR,NI), PL(NI) , ATM(AI),

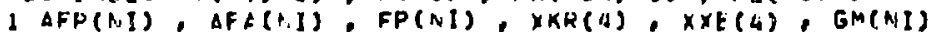

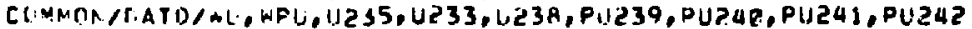

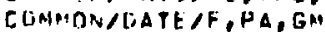

SLBROLITINE CAICLLATFS THE MCLES OF FISSIGA PROUUCTS GENERATEO IN FUEL SAMPIE CIINTAINING UHARIUN AND PLUTRRIUM JRRACIATED IN EBKD?

FISSION PRODI:CT YJELNS OATAINFD FROM NECO-12154 (JAN 1972)

AXJAL. FISSION VARIATIUN CALCULATED ASSLMING CHOPPED COSINE AXIAL VARIATION HACH FI CALCULATEI SEPARATEIY HASED DIS P(I,K) DATA

$Y(I, J)=$ HR C.H MULFS OF FP J FOUM FI I PEK IOOO ROLES OF I FISSIONED

PLI (I) $=$ PA(K,J) CORRFCTEC FOR FUEL COLUMH IESS THAR 13.5 IN

FISSIONAALE ISOTOPF IDEMTIF ICATION

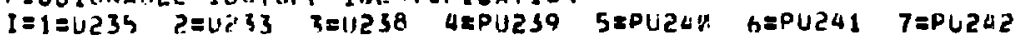

FISSION PQOOULT IDENTIFICATION 


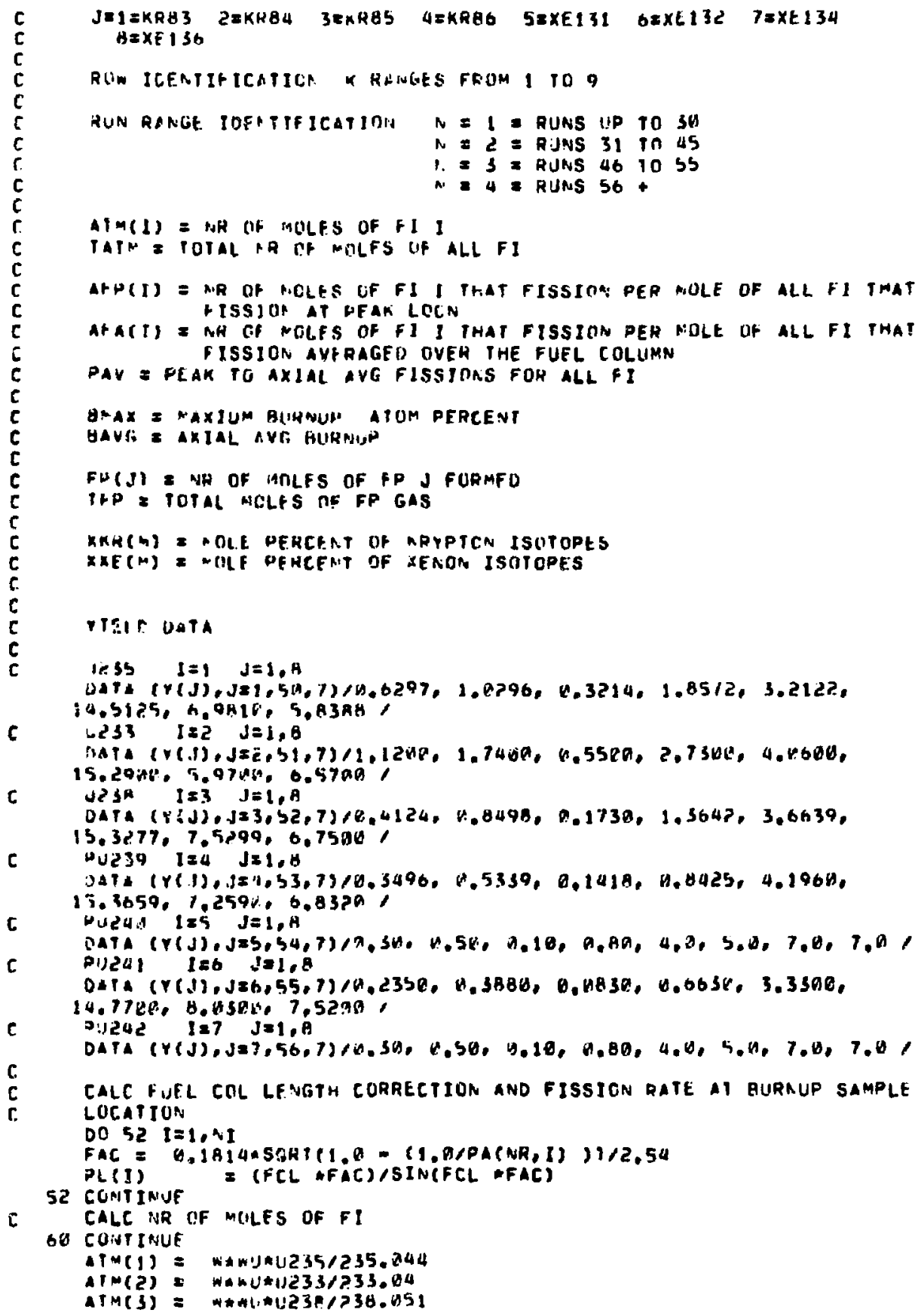




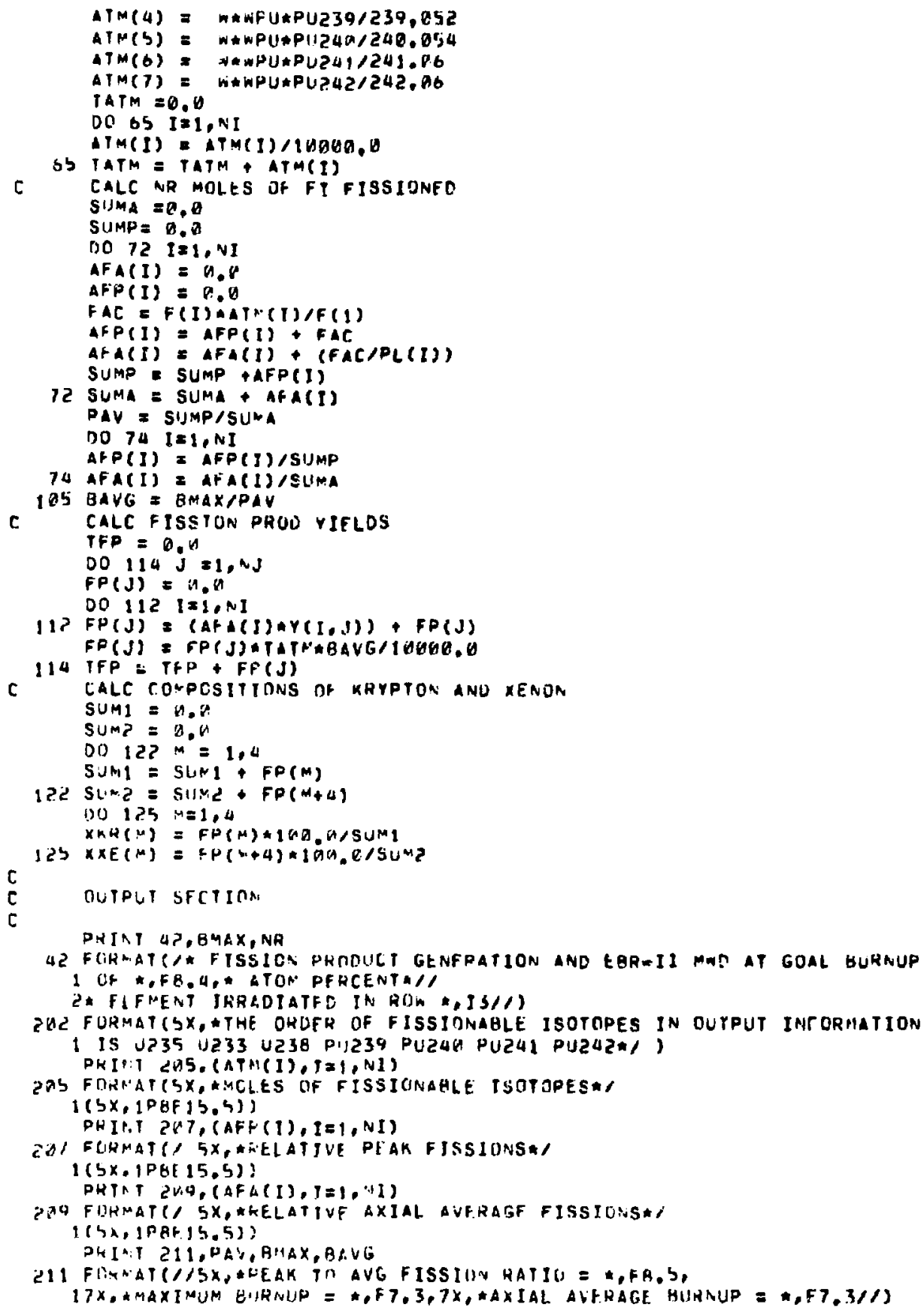


PHINT $213,(F P(3), j=1$, NiJ)

2.13 FORMATCSX, MMOLES OF FISSION PHODUCTS GERERATEDA'

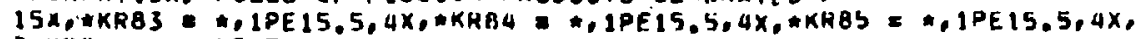
$2 \times K 486=1,1$ PE 15,51

$35 \times, * x E 131=\ldots, 1 P E 15,5,4 x, * x E 132=*, 1 P E 15,5,4 x, * x E 134=*, 1 P F 15,5$, $44 \times, * X E 136=1,3 P F 15,5 / 1)$

PHINT 215, TFP, SUM1, S11M2

215 FORMATC5X, TRTAL MOLES OF FISSIUN GAS $=\ldots 1 P F 15.5,1 X^{\circ}$ 1. MOLES KR $A, 1 P F 15,5,7 x$, *MOLES XE $=*, 1 P E 15.5 / 13$

PRINT $217,(X K R(M), M=1,4)$

217 FORMATC5X, \#KRYPTON ISOTOPIC COMPOSITION MOL.E PERCENTA

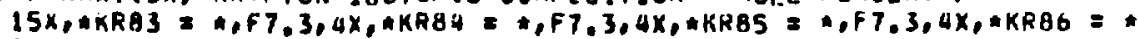
$2,+7,3 / 13$

PRINIT $219,(X \times F(M), M=1,4)$

219 FOHMATC5X, AXEHON ISOTOPIC CUMPOSITION MOLE PERCEHT: $15 x_{0} \star X E 131=\star, F 7,3,4 x_{0} \star x E 132=\star, F 7,3,4 x_{0} \star x E 934=\pi, F 7,3,4 x_{1}$ $2 \times \times 136=0,7,3 / 13$

C CALC EBR-II IRRADIATION TIME ANO MHO

APON $=62.5$

SUHM $=0.0$

OU $335 t: 1, N I$

: 35 SUMN $=$ SUAM + $\{F(1) * G M(1))$

SUMM = SUMMAVOL/(TATM\#G. A2 3t +23)

TIRR = AMAX/CSUMMA24AO, (A*36(A), B)

XMAD $=$ TIRRARPOW

PRIT.T 225, TIRR,RPOA, XMMU

225 FORMATC IRRAUIATION :IME * \#F7.1, DAYS AT A,FG.Z," MN REACTOR P IOWFR FOR A TCTAL OF \#,FA,, , MWO IV FGH-II*I

RETUHN

ENO 